\title{
Energy requirement of Korean households from 1995 to 2010: An input-output analysis-
}

\author{
Hi-chun Park*
}

ABSTRACT : As energy conservation can be realized through changes in the composition of goods and services consumed, there is a need to assess indirect and total household energy consumption. The Korean household sector was responsible for more than 55\% of Korea's total energy consumption in the 1995 to 2010 period. More than $69 \%$ of household energy consumption was indirect. Thus, not only direct but also indirect household energy consumption should be the target of energy conservation. Electricity consumption became in 2009 the main source of household energy consumption in Korea. Households consume more and more electricity intensive goods and services, a sign of increasing living standards. Decrease in energy intensities of products consumed by Korean households contributed greatly to reduce the increase in the total household energy consumption. However, switching took place towards more energy intensive products, thus the structure effect was negative. It is necessary to direct consumption and production towards much less energy intensive goods and services as to reduce energy consumption or its growth rate. The Korean government should readjust low energy and electricity prices to cost-reflective prices levels as these low prices are one of the main reasons for the consumption of more energy intensive products. This study differentiates prices of oil products and electricity between households and industries, as to allow more accurate estimation.

Keywords : Household energy consumption, Indirect energy consumption, Energy input-output analysis

Received: May 26, 2013. Revised: September 2, 2013. Accepted: September 13, 2013.

* Department of Economics, Inha University (e-mail: hi-chun.park@inha.ac.kr) 


\title{
한국 가정부문의 직간접 에너지소비: 산업연관분석
}

\author{
박 희 천*
}

요 약 : 상품 및 서비스 소비구조의 변경을 통해 에너지절약이 실현될 수 있기 때문에 가정부문 의 간접 및 총 에너지소비를 추정할 필요가 있다. 가정부문의 직간접 에너지소비를 보다 정확 히 추정하기 위해 본 연구는 기업과 소비자(가정부문) 간 석유제품 및 전력의 가격을 차별화하 였다. 한국의 가정부문은 1995-2010년 기간 중 한국 1차 에너지소비 중 $55 \%$ 이상을 소비하였 다. 가정부문의 에너지소비 중 $69 \%$ 이상이 간접 에너지소비였다. 따라서 가정부문의 직접뿐만 아니라 간접 에너지소비도 에너지절약의 대상이 되어야 한다. 전력 소비는 2009년 한국의 가정 부문의 주 에너지소비가 되었다. 생활수준이 향상됨으로써 가정부문은 전력 원단위가 높은 상 품과 서비스를 소비하게 되었다.

한국 가정부문이 소비하는 제품의 에너지 원단위가 낮아짐으로써, 에너지소비의 증가율이 감소 하게 되었다. 반면에 한국 가정부문의 상품 및 서비스 소비구조는 에너지 다소비형으로 변경되 어 오히려 에너지소비 증가를 가속시키는 결과를 초래함으로써, 구조효과는 악화되었다. 이에 따라 에너지정책은 에너지소비를 감소시키기 위해 소비자로 하여금 에너지 저소비형 재화와 용역을 소비하도록 유도하여야 한다. 에너지 저소비형 소비를 촉진시킬 수 있는 주요 수단인 에너지가격 현실화가 요구된다.

주제어 : 가정부문 에너지소비, 간접에너지, 산업연관분석

접수일(2013년 5월 26일), 수정일(2013년 9월 2일), 게재확정일(2013년 9월 13일)

*인하대학교 경제학부 교수(e-mail: hi-chun.park@inha.ac.kr) 


\section{Introduction}

The Korean economy has been very energy intensive. Korea consumed energy in the amount of 93.087 Mtoe (million tons of oil equivalent) in 1990, 188.161 Mtoe in 2000 and 249.964 Mtoe in 2010, according to the International Energy Agency statistics (IEA, 2012). Although the annual average growth rate of energy consumption slowed down from $7.3 \%$ in the 1990 s to $2.9 \%$ in the 2000 s, it is very alarming. Korea was ranked $10^{\text {th }}$ in the world for its energy consumption in 2010 . Only China, the USA, Russia, India, Japan, Germany, Brazil, France and Canada consumed energy more than Korea. The Korean per capita energy consumption was 5.1153 toe or $14 \mathrm{GJ}$ in 2010. This consumption amount was higher than that of the OECD Europe (3.2910 toe) and the OECD Asia Oceania (4.3293 toe) and lower than that of the OECD Americas (5.7010 toe).

The first step for the energy conservation is to assess energy consumption by economic activities like consumption, investments and exports and by industrial sectors. Korean households (private consumption in the national accounts) spend a lion's share of GDP for consumption. Korean households (private consumption in the national accounts) spend a lion's share of GDP for consumption. The household consumption expenditure amounted to 617.1 trillion Korean Won (TWon) or USD 533 billion, corresponding to $59.1 \%$ of GDP in 2010. Often the discussion focuses on direct energy consumption in the form of electricity, fuel oil, gasoline, town gas and district heat by households. Many households are not paying much attention to energy conservation as a relatively small portion of their income is spent for direct energy use. In 2010 the Korean households spent only $6.1 \%$ of their incomes to pay energy utility bills and to buy gasoline, diesel and Liquefied Petroleum Gas (LPG) for their cars according to the 2010 input-output tables of the Bank of Korea (BOK, 2012).

However, the households cause substantial energy consumption embodied in the 
goods and services they consume. The so-called indirect energy consumption depends on energy intensities of products consumed and on the mix of products consumed, hence on the household consumption behavior/ pattern. Energy conservation can be realized, if consumption can be directed towards less energy intensive products. The first step for such conservation is the quantification of total (direct and indirect) household energy consumption. This study aims to quantify direct and indirect household energy consumption in Korea from 1995 to 2010 by using 168 sector classification input-output tables.

This study discusses first the way in which the household energy consumption can be calculated. (Monetary) input-output tables are transformed to energy inputoutput tables. Next, income development and energy consumption in Korea from 1995 to 2010 are briefly described. Then the paper presents the results concerning direct and total energy intensities, direct, indirect and total household energy consumption as well as causes of the increase in energy consumption over the studied period. At the end some limitations of this study are discussed and some conclusions are drawn.

\section{Quantification of the household energy consumption}

Well established are the two basic methods to quantify indirect energy consumption or indirect energy consumption, e.g., process chain analysis and input-output analysis, and hybrid combination of the two methods. The process chain analysis or life-cycle assessment calculates indirect energy consumption or indirect energy consumption by adding up energy inputs or energy inputs (contents) in all stages of the production process of a product or a service. This method enables to assess indirect energy consumption or energy emission in a very detailed manner. However it is very work intensive and requires a detailed database (IFIAS, 1978; Boustead and Hancock, 1979; Schaefer, 1982; SETAC, 1993) and it is typically used for assessing individual products or services. 
The input-output analysis computes with the help of the Leontief inverse intermediate or cumulative energy inputs or cumulative energy inputs (contents) of a sector/ branch. This analysis can be applied easily to all sectors regardless length and complexity of their production processes. However, as the number of the sectors in a national input-output table is limited, for instance, to 403 in the case of Korea, product specific energy consumptions cannot be considered (Wright, 1974; Bullard and Herendeen, 1975; Denton, 1975; Pick and Becker, 1975; Miller and Blair, 1985; Peet et al., 1985; Peet, 1993; Ospelt et al., 1996; Lenzen, 1998; Pachauri, 2002; Pachauri and Spreng, 2002; Park and Heo, 2007; Vringer et al., 2009).

The hybrid method seeks to use advantages of both methods. In other words, the process chain analysis is used to calculate energy consumption or energy emission of energy intensive or energy intensive products and the input-output analysis is applied to calculate that of other products. Suh et al. (2004) classifies hybrid approaches in three groups, e.g., tiered hybrid analysis, input-output based analysis and integrated hybrid analysis. To calculate the total energy consumption of Dutch households, Vringer and Blok (1995a, 1995b, 2000) used the so-called tiered hybrid energy analysis. They determined the energy intensities of about 350 basic consumption categories using the expenditure of 2767 representative households from the Netherlands Household Expenditure Survey of 1990. Although they analyzed changes in consumption patterns of Dutch households in the period from 1948 to 1996, information on energy intensities of only one year (1990) was used (available). This method is also work intensive and requires detailed data (van Engelenberg et al., 1994; Vringer and Blok, 1995a, 1995b, 2000; Vringer et al., 2009).

This study applies input-output analysis and uses relatively disaggregated input-output tables for Korea from 1995 to 2010. It converts monetary input-output tables into energy input-output tables. Used are 168 sector classification input-output tables for Korea for the years 1995, 2000, 2005, 2009 and 2010 published by the Bank of Korea (BOK, 2008, 2012), both in current and constant prices. The 168 
sectors consist of 161 non-energy sectors and 7 energy sectors which are naphtha, oil products (gasoline, diesel, kerosene, LPG, aviation fuel and fuel oil), other oil products (white spirit \& SBP, lubricants, bitumen, solvent, paraffin waxes, petroleum coke etc.), coal products, electricity, town gas, and steam \& district heat. Inputoutput tables in constant deflated prices provided by the Bank of Korea are used to calculate energy intensities as to make the values for different years comparable. There are 168 sector classification input-output tables for the years 1995, 2000, 2005 and 2009 in 2005 constant prices. For comparison, 168 sector classification input-output tables for the years 1995, 2000, 2005, 2009 and 2010 in current prices are also used.

Energy consumption data for the entire period are taken from the Energy Balances of OECD Countries of the International Energy Agency (IEA, 2012). However, these data are not detailed enough to construct 7 (energy sectors) ' 168 energy input-output tables which are needed to calculate 168 direct energy intensities. The IEA energy statistics gives information on energy consumption of only following sectors: agriculture/ forestry; fishing; 13 manufacturing sectors; 6 transportation sectors; residential; commercial and public services and non-energy use.

Moreover, energy consumption data are given in final energy terms (total final consumption, TFC) in the IEA energy statistics. This study converts these data in primary energy terms (total primary energy supply, TPES, Table 1) as not to favor those sectors especially with a higher share of electricity in the total energy consumption in calculating energy intensities. Sectors with a higher share of electricity require larger amount of primary energy equivalents than those with a lower share if energy intensities are calculated in final energy equivalents. The IEA energy consumption data in million tons of oil equivalent (Mtoe) are converted to Peta Joule (PJ) by multiplying with 41.868 , thus 1 Mtoe is equal to 41.868 PJ. 
$<$ Table $1>$ Final and primary energy consumption in 2010 (PJ).

\begin{tabular}{lccc}
\hline & $\begin{array}{c}\text { Total final energy } \\
\text { consumption (TFC) }\end{array}$ & $\begin{array}{c}\text { Energy balance for 2010 } \\
\text { Total primary energy } \\
\text { supply (TPES) }\end{array}$ & $\begin{array}{c}\text { Transformation } \\
\text { efficiency }\end{array}$ \\
\hline Naphtha & 1371.7 & 1539.1 & $89.1 \%$ \\
Oil products & 1916.4 & 2150.2 & $89.1 \%$ \\
Other oil products & 139.5 & 156.5 & $89.1 \%$ \\
Coal products & 399.6 & 523.1 & $76.4 \%$ \\
Town gas & 852.5 & 905.6 & $94.1 \%$ \\
Electricity & 1617.9 & 4832.2 & $33.5 \%$ \\
Steam \& district heat & 181.3 & 237.9 & $76.2 \%$ \\
Renewables & 112.7 & 122.8 & $91.8 \%$ \\
Total & 6591.6 & 10467.4 & $63.0 \%$ \\
\hline
\end{tabular}

Source: IEA (2012)

Note: The differences between TPES and TFC include conversi on loss, own use \& distribution loss.

Furthermore, this study excludes renewable sources of energy amounting to 116.9 PJ or about $1.1 \%$ of the TPES in 2010 , as it is difficult to allocate its consumption to individual sectors.

The monetary input-output system can be formulated in Eqs. (1)-(2).1)

$$
\begin{aligned}
& \sum_{i=j=1}^{168} a_{1 j} X_{i}+Y_{1}-I M_{1}=X_{1} \\
& \sum_{i=1}^{7} a_{i 1} X_{i}+\sum_{i=8}^{168} a_{i 1} X_{i}+V_{1}=X_{1} \\
& \text { with } \sum_{i=j=1}^{168} a_{i j}<1
\end{aligned}
$$

where $X_{1}$ is the gross domestic output (production)2) or the total input of sector 1 . The gross domestic output $X_{l}$ of sector 1 consists of the total intermediate demand

1) The approach used to develop energy input-output tables is based on Park and Heo (2007).

2) The Gross domestic output is equal to the total demand (the total intermediate demand and total final demand) minus imports in the terminology of input-output tables or national accounts. 
$\sum_{i=1}^{168} a_{1 j} X_{i}$ and the total final demand $Y_{1}$ minus imports $I M_{l}$ as shown in Eq. (1). The total intermediate demand of sector 1, e.g., naphtha, $\sum_{i=j=1}^{168} a_{1 j} X_{i}$ are the products of sector 1 to be used for the production of goods of sectors 1 to 168 and $\sum_{i=1}^{168} a_{i 1} X_{i}$ are the total intermediate inputs from sectors 1 to 168 for the production of goods of sector $1 . Y$ is the total final demand which includes consumption (private and government), investments, exports and stock changes. $I M$ is the imports and $V$ is the value added inputs. The first summation of Eq. (2) means the inputs of 7 energy sources (carriers). The second summation of Eq. (2) means the inputs of 161 non-energy sectors.

In the first step, this study transforms (monetary) input-output tables into energy input-output tables with the help of average (uniform) energy prices. Such energy prices are calculated as ratios of energy use (inputs by fuel) $E i$ to the gross domestic output $X i$ or the total demand (IMi) by fuel, expressed in $\mathrm{kJ} / \mathrm{Won}$, same as energy intensities as shown in Eq. (3). The reciprocal numbers of the energy intensities are more commonly used prices expressed in Won/kJ. Thus, higher $\mathrm{kJ} /$ Won values or higher energy intensities mean lower energy prices and vice versa (Energy prices in $\mathrm{kJ} /$ Won for the 1995 to 2009 period are given in Table 3).

$$
P_{i}=\frac{E_{i}}{X_{i}} \text { or } \frac{E_{i}}{T d_{i}-I M_{i}}(k J / \text { Won })
$$

where $E i$ is energy use or energy consumption. First, we apply the uniform fuel prices to convert monetary into energy input-output tables. $P_{l}$, the average price of energy sector 1, e.g., price of naphtha, is used to quantify 168 intermediate inputs of naphtha to produce goods of 168 sectors in Eq. (4). 


$$
\sum_{i=j=1}^{168} a_{1 j} X_{i} * P_{1}=\sum_{j=1}^{168} E_{1 j}
$$

Once intermediate energy inputs (energy input-output tables) are computed as in Eq. (4), it is easy to estimate direct energy intensities (by fuel) of individual sectors. Direct energy intensities of sector 1 are calculated as ratios of direct energy expenditure converted in energy terms to the total input (intermediate inputs and value added inputs) of sector 1, also expressed in $\mathrm{kJ} /$ Won in Eq. (5).

$$
\sum_{i=1}^{7} I_{i 1}(\text { direct })=\frac{\sum_{i=1}^{7} E_{i 1}}{X_{1}}(k J / \text { Won })
$$

where $I_{1}$ (direct) is the direct energy intensity of sector 1 (the sum of 7 direct intensities). Total or cumulative energy intensities (e.g., energy sector 1, naphtha intensities) of 168 sectors can be then computed by multiplying direct energy (naphtha) intensities with the Leontief inverse $\sum(I-A)^{-1}$ of the corresponding input-output table as expressed in Eq. (6).

$$
\sum_{i=1}^{168} I_{1 j}(\text { direct }) * \sum_{i=j=1}^{168}(I-A)^{-1}=\sum_{j=1}^{168} I_{1 j}(\text { total })
$$

The indirect energy intensities are the differences between total (Eq. (6)) and direct energy intensities (Eq. (5)). Sectoral total or cumulative energy consumption can be computed by multiplying total energy intensity with sectoral household (private consumption) expenditure. Indirect household energy consumption is then the sum of sectoral cumulative energy consumptions. Direct use of oil products, other oil products, coal products, electricity, town gas, and steam \& district heat in 
primary energy terms by households is considered as direct household energy consumption. Total household energy consumption is the sum of direct and indirect household energy consumption.

Uniform (average) prices for fuels to all 168 sectors (total intermediate demand) and total final demand (consumption, investments and exports) minus imports are not without problem. Industries (168 sectors) will pay much lower prices than households (private consumption expenditure) for the same fuel. The price differential exists within the intermediate demand for fuels. For more discussions see Lenzen (1998).

In the second step, fuel prices are differentiated between industries (the total intermediate demand, investments, stock change, exports and imports) and consumption (households and public consumption). From 7 fuels under consideration only oil products and electricity prices are differentiated. Naphtha, the feedstock for the petrochemical industry is used only in the industry. Coal products are used mostly for power generation and iron \& steel and cement production in the industry. In 2010 the Korean households consumed coal in the form of briquettes in the amount of 35.8 PJ. In comparison the industrial coal consumption was $885.5 \mathrm{PJ}$ in the same year. Coal briquettes are heavily subsidized in Korea as these are considered fuels for very low income households. Thus, one can consider that there is hardly any coal price differential between industries and households. Other oil products are also used mostly in industries.

The Korean natural gas market has been regulated. There have been cross subsidies from the industry and the commercial sector to households in the gas market. The costs of storage of liquefied natural gas (LNG) in summer months, caused by household low gas demand in summer months and high gas demand in winter months, are shared evenly between industries and households. In general Korean households do not pay more for natural gas than industries. The heat market has been also regulated. Korean households pay for district heat less than 
the commercial and public sectors. The tariffs for district heat of the Korea District Heat Corporation, which supplies more than $50 \%$ of district heat in Korea, were Won 79.28/Mcal (1 Mcal = 4.1868 MJ) for households, Won 102.83/Mcal for the commercial sector and Won 89.90/Mcal for the public sector as of 1 June 2012. The share of the commercial and public sectors in the district heat market is small. The industry does not use district heat of $120^{\circ} \mathrm{C}$ heat but steam which is different from district heat. The tariffs for steam are for low steam $\left(200^{\circ} \mathrm{C}\right)$ Won $77.90 / \mathrm{Mcal}$, for middle steam $\left(285^{\circ} \mathrm{C}\right)$ Won $88.55 / \mathrm{Mcal}$ and high steam $\left(380^{\circ} \mathrm{C}\right)$ Won $\left.99.08 / \mathrm{Mcal} .{ }^{3}\right)$ This study assumes no substantial difference in the heat price between households and industries.

$<$ Table $2>$ Electricity tariffs in Won per kWh.

\begin{tabular}{cccccc}
\hline & Industry (Ind) & Residential (Res) & Industry & Residential & Ind to Res ratio applied \\
\hline 1995 & 46.14 & 86.47 & 100.0 & 187.4 & 1 to 1.8 \\
2000 & 58.30 & 94.72 & 100.0 & 162.5 & 1 to 1.6 \\
2005 & 60.25 & 91.07 & 100.0 & 151.2 & 1 to 1.5 \\
2009 & 73.69 & 98.07 & 100.0 & 133.1 & 1 to 1.3 \\
2010 & 76.63 & 103.38 & 100.0 & 134.9 & 1 to 1.3 \\
\hline \multicolumn{7}{l}{ Source: Korea Electric Power Corporation. }
\end{tabular}

In the electricity market there is only one supplier, the state-owned Korea Electric Power Corporation (KEPCO). The electricity tariffs apply to the whole country without any exception to individual companies. Table 2 shows that Korean households paid $30 \%$ to $80 \%$ more than industries. This study assumes the industry to residential tariff ratios for individual years as given in Table 2.

In the electricity market there is only one supplier, the state-owned Korea Electric Power Corporation (KEPCO). The electricity tariffs apply to the whole country without any exception to individual companies. Table 2 shows that Korean households paid $30 \%$ to $80 \%$ more than industries. This study assumes the industry to residential tariff ratios for individual years as given in Table 2.

3) Information is provided from a large petrochemical company which sells also steam to other companies in a large petrochemical complex in Korea. 
Households consume highly taxed fuels such as gasoline and diesel and LPG for transport and fuel oil for heating while the industry uses less taxed petroleum products such as fuel oil and diesel as well as LPG for the production of synthetic gas. At the same time, households pay more than the industry for the same fuel. This study assumes that households pay on average 30\% more than the industry.

$<$ Table 3> Fuel prices cum energy intensities applied in kJ per Won.

\begin{tabular}{lrrrr}
\hline & 1995 & 2000 & 2005 & 2009 \\
\hline Naphtha & 123.2 & 105.7 & 125.3 & 143.5 \\
Oil products (uniform price) & 51.8 & 38.4 & 38.2 & 33.8 \\
$\quad$ for industries & 55.3 & 41.1 & 40.3 & 35.7 \\
for households & 42.7 & 31.6 & 31.0 & 27.5 \\
Other oil products & 34.1 & 46.0 & 34.9 & 24.8 \\
Coal & 141.9 & 181.7 & 150.9 & 186.9 \\
Electricity (uniform price) & 132.8 & 145.0 & 136.4 & 139.0 \\
$\quad$ for industries & 145.3 & 157.2 & 146.2 & 146.9 \\
for households & 80.7 & 98.3 & 97.4 & 113.0 \\
Gas & 45.8 & 55.7 & 52.9 & 54.8 \\
Heat & 45.1 & 101.4 & 117.2 & 141.3 \\
\hline
\end{tabular}

According to Table 3, the average prices of oil products and other oil products increased from $51.8 \mathrm{~kJ} /$ Won and $33.8 \mathrm{~kJ} /$ Won in 1995 to $34.1 \mathrm{~kJ} /$ Won and 24.8 $\mathrm{kJ} /$ Won in 2009, respectively. These were expensive fuels in Korea. There were little changes in prices of fuels like naphtha and electricity. It is important to note that prices of electricity are lower than primary fuels like oil products and natural gas. The electricity prices are low partly because of a large share of nuclear power generation and partly because of a low electricity price policy in Korea.

\section{Income development and energy consumption in Korea}

Before presenting the findings of this study a brief description on income development and energy consumption in Korea from 1995 to 2010 is given. The annual average income (GDP) growth was 5.2\% in the second half of 1990s as shown 
in Table 4. It slowed down in the 2000s. The increase in household consumption expenditure decreased from $6.7 \%$ per year in the second half of the 1990 s to $4.6 \%$ per year in the 2000s. The annual growth rate of total household primary energy consumption increased from $1.9 \%$ in the first period to $2.1 \%$ in the second period. The increase in direct household primary energy consumption decreased substantially from $4.4 \%$ in the 1995 to 2000 period to $0.6 \%$ in the 2000 s. Thus, the income (consumption expenditure) elasticity of energy demand decreased substantially from $0.66(4.4 / 6.7)$ in the first period to $0.13(0.6 / 4.6)$ in the second period. The relatively high income elasticity in the second half of the 1990s was due to heavy investments in iron \& steel and petrochemical industries since the late 1980s, which was one of the causes of the Asian economic crisis in Korea. Large investments were made in energy intensive industries such as petrochemical, iron \& steel, and cement industries. For instance, the production capacity of ethylene, a major basic chemical, increased from $0.505 \mathrm{Mt}$ (million tons) in 1988 to $5.150 \mathrm{Mt}$ in 2000 . Indeed, Korea's industry is very energy intensive. Korea's iron \& steel industry ranks fifth and Korea's petrochemical industry measured in ethylene production ranks sixth in the world. The high per capita TPES in Korea is partly due to a large share of heavy industry in the economy.

$<$ Table 4> Income development and energy consumption in Korea (1995-2010).

\begin{tabular}{|c|c|c|c|c|c|}
\hline & \multirow{2}{*}{1995} & \multirow{2}{*}{2000} & \multirow{2}{*}{2010} & \multicolumn{2}{|c|}{ Annual grow th rates in $\%$} \\
\hline & & & & $1995-2000$ & $2000-2010$ \\
\hline GDP in TWon at 2005 constant prices & 539.7 & 695.0 & $1,043.8$ & 5.2 & 4.2 \\
\hline $\begin{array}{l}\text { Hous ehold consumption in TWon at } 2005 \text { prices } \\
\text { (Household consumption share in GDP in \%) }\end{array}$ & $\begin{array}{l}283.8 \\
(52.6)\end{array}$ & $\begin{array}{l}392.3 \\
(56.4)\end{array}$ & $\begin{array}{l}617.0 \\
(59.1)\end{array}$ & 6.7 & 4.6 \\
\hline Per capita GNI at current USD & 11,735 & 11,292 & 20,562 & -0.8 & 6.2 \\
\hline Exchange rate Won/USD & 770.94 & $1,131.12$ & $1,156.30$ & & \\
\hline Population in million & 45.093 & 47.008 & 48.875 & 0.8 & 0.4 \\
\hline Total primary en ergy supply (TPES, in PJ) & $6,060.6$ & $7,877.9$ & $10,467.4$ & 5.4 & 2.9 \\
\hline (Percapita TPES in GJ) & (134.4) & $(167.6)$ & $(214.2)$ & 4.5 & 2.5 \\
\hline Total household primary energy use (PJ) & $4,166.6$ & $4,567.7$ & $5,602.0$ & 1.9 & 2.1 \\
\hline (Per capita total household energy in GJ) & $(95.4)$ & $(97.2)$ & (114.6) & 0.4 & 1.7 \\
\hline Direct household primary energy use (PJ) & $1,126.8$ & $1,399.7$ & $1,481.9$ & 4.4 & 0.6 \\
\hline (Per capita direct household energy in GJ) & $(25.0)$ & $(29.8)$ & $(30.3)$ & 3.6 & 0.2 \\
\hline
\end{tabular}

Sources: BOK, IEA and own calculation.

Notes: $\mathrm{G}=$ Giga, $\mathrm{T}=\mathrm{T}$ era or trillion, $\mathrm{P}=$ Peta, $\mathrm{RA}=$ Reference Approach, $\mathrm{SA}=$ Sectoral Approach. 
For a per capita income of USD 19,720 economy the per capita primary energy consumption of 214.2 GJ in 2010 was very high. In comparison, the per capita primary energy consumption for France, Germany and Japan were 169.3 GJ. 167.6 GJ and 163.3 GJ, respectively according to the IEA Statistics. And the per capita income for France, Germany and Japan were USD 42,190, USD 43,280 and USD 42,050 , respectively according to the World Bank. The shares of the Korean household consumption in GDP were with between $52.3 \%$ (1995) to $54.5 \%$ (2000) smaller than most OECD countries.

< Table 5> Energy consumption patterns in international comparison for the year 2010.

\begin{tabular}{|c|c|c|c|c|c|c|}
\hline & & Korea & Japan & France & Germany & USA \\
\hline Consumption (TFC) & by sector & & & & & \\
\hline Household & $\%$ & 12.6 & 15.3 & 27.1 & 27.4 & 17.9 \\
\hline Industry & $\%$ & 28.4 & 27.7 & 18.0 & 24.3 & 18.7 \\
\hline Transportation & $\%$ & 19.0 & 23.7 & 27.2 & 23.4 & 38.9 \\
\hline Commercial & $\%$ & 13.0 & 19.8 & 14.4 & 14.2 & 13.7 \\
\hline Non-energy use & $\%$ & 24.4 & 12.3 & 7.4 & 10.4 & 9.0 \\
\hline Consumption & per capita & & & & & \\
\hline Total & GJ/capita & 214.2 & 163.3 & 169.3 & 167.6 & 299.2 \\
\hline Households & GJ/capita & 17.01 & 16.33 & 28.44 & 31.76 & 36.22 \\
\hline \multirow{3}{*}{ Industry } & GJ/capita(adjusted) & 23.78 & 29.27 & 41.97 & 41.13 & 61.40 \\
\hline & GJ/capita & 38.34 & 29.59 & 18.93 & 28.24 & 37.80 \\
\hline & GJ/capita(adjusted) & 63.55 & 43.74 & 28.71 & 43.12 & 53.11 \\
\hline Iron \& ste el & $\mathrm{GJ} /$ capita & 8.94 & 7.15 & 2.32 & 4.17 & 2.75 \\
\hline Non-energy use & GJ/capita & 32.86 & 13.11 & 7.75 & 12.11 & 18.18 \\
\hline Consumption & of electricity & & & & & \\
\hline Total & $\mathrm{kWh}$ /capita & 9,851 & 8,399 & 7,756 & 7,217 & 13,361 \\
\hline Household & $\mathrm{kWh}$ /capita & 1,254 & 2,396 & 2,505 & 1,734 & 4,662 \\
\hline Industry & $\mathrm{kWh}$ /capita & 4,667 & 2,619 & 1,811 & 2,756 & 2,836 \\
\hline
\end{tabular}

Table 5 shows that the share of household consumption in total final consumption is lowest among OECD countries in comparison, while its share of the industry together with non-energy use (mostly petrochemical industry) is highest among these countries in 2010. Per capita household electricity consumption was with 
$1254 \mathrm{kWh}$ the lowest, while per capita industry electricity consumption was with $4337 \mathrm{kWh}$ the highest in 2010. The energy consumption grew a little slower than the total primary energy supply but depended in general on its growth rates.

Table 6 shows that the per capita energy consumption of 5.12 toe in 2010 was very high in comparison to most OECD countries. Korea consumed more energy per capita or per GDP production than most OECD countries in 2010. Only the Netherlands recorded almost the same per capita energy as Korea. However, Korea's energy consumption per GDP production was much higher than other OECD countries in comparison.

$<$ Table 6> Energy consumption in international comparison (2010).

\begin{tabular}{lccc}
\hline & $\begin{array}{c}\text { TPES/Population } \\
\text { toe per capi ta }\end{array}$ & $\begin{array}{c}\text { TPES/GDP } \\
\text { toe per 1000 US\$ } \text { 2005 }\end{array}$ & $\begin{array}{c}\text { TPES/GDPPPP } \\
\text { toe per US } \$_{2005}\end{array}$ \\
\hline Korea & 5.1153 & 0.2457 & 0.1893 \\
France & 4.0447 & 0.1188 & 0.1364 \\
Germany & 4.0042 & 0.1111 & 0.1198 \\
Japan & 3.9004 & 0.1085 & 0.1276 \\
Netherl ands & 5.0220 & 0.1218 & 0.1357 \\
United Kingdom & 3.2567 & 0.0866 & 0.1002 \\
\hline
\end{tabular}

Source: IEA, Energy Balances of OECD Countries (IEA, 2012).

Note: 1 toe is equal to $41.868 \mathrm{GJ}$.

\section{Results}

\section{Energy intensities}

Table 7 lists direct energy intensities of the 15 most energy intensive non-energy sectors as of 2009, expressed in kJ per Won in 2005 constant prices. The average direct energy intensity decreased from 1995 to 2009. However, the energy intensities of several sectors like warehouse and storage, agriculture, forestry and fishing related service and starches and other sugar increased from 2000 to 2009 or from 2005 to 2009. The energy intensity of agriculture, forestry and fishing 
related service, increased substantially from $3.78 \mathrm{~kJ}$ per Won in 1995 to $14.08 \mathrm{~kJ}$ Won in 2009. This sector has been using more and more electricity. Indeed, electricity is heavily subsidized for the agriculture in Korea. As a consequence greenhouses to cultivate vegetables and fruits have changed as heating fuel from fuel oil or coal briquettes to electricity. With the increasing income and living standard required are more cooling and refrigeration of meat and vegetables in warehouses and storage facilities in Korea.

$<$ Table $7>$ Direct energy intensity of most intensive non-energy sectors in Korea (1995-2009).

\begin{tabular}{|c|c|c|c|c|c|c|c|c|}
\hline & \multicolumn{2}{|c|}{1995} & \multicolumn{2}{|c|}{2000} & \multicolumn{2}{|c|}{2005} & \multicolumn{2}{|c|}{2009} \\
\hline & \multicolumn{2}{|c|}{$\mathrm{kJ} / \mathrm{Won}_{2005}$} & \multicolumn{2}{|c|}{$\mathrm{kJ} / \mathrm{Won}_{2005}$} & \multicolumn{2}{|c|}{$\mathrm{kJ} / \mathrm{Won}_{2005}$} & \multicolumn{2}{|c|}{$\mathrm{kJ} / \mathrm{Won}_{2005}$} \\
\hline & Intensity & Direct share & Intensity & Direct share & Intensity & Direct share & Intensity & Direct share \\
\hline Petrochemical basic products & 97.79 & 85.4 & 80.23 & 91.3 & 92.41 & 85.8 & 73.25 & 65.9 \\
\hline Pig iron and ferroalloys & 81.67 & 91.4 & 68.90 & 86.3 & 31.40 & 72.5 & 49.67 & 75.9 \\
\hline Warchousing and storage & 10.22 & 85.4 & 9.37 & 69.6 & 15.43 & 78.3 & 18.29 & 77.0 \\
\hline Fiber blexhing and dyeing & 13.40 & 57.5 & 14.15 & 42.7 & 13.81 & 48.4 & 14.32 & 43.9 \\
\hline Agriculture, forestry and fishing related services & 3.78 & 49.8 & 4.44 & 60.0 & 12.38 & 72.4 & 14.08 & 68.3 \\
\hline Inorganic basic chemical products & 20.25 & 66.7 & 20.58 & 51.0 & 15.50 & 47.6 & 12.48 & 39.9 \\
\hline Fiberyarn & 6.08 & 41.8 & 6.01 & 20.3 & 11.70 & 36.6 & 12.41 & 32.7 \\
\hline Cement & 16.87 & 33.5 & 19.71 & 62.5 & 16.64 & 62.0 & 12.24 & 51.4 \\
\hline Paper & 7.94 & 59.3 & 9.41 & 37.9 & 12.65 & 43.6 & 11.28 & 39.5 \\
\hline Water supply & 9.98 & 19.2 & 10.69 & 60.5 & 11.69 & 62.2 & 11.22 & 62.1 \\
\hline Pulp & 14.73 & 57.7 & 10.17 & 42.3 & 10.32 & 41.5 & 11.03 & 40.1 \\
\hline Clay products & 14.31 & 79.6 & 14.86 & 55.6 & 10.23 & 54.0 & 10.70 & 50.5 \\
\hline Rail transport & 13.81 & 827 & 12.63 & 74.3 & 11.49 & 73.5 & 10.30 & 69.8 \\
\hline Starches and other sugars & 4.60 & 56.9 & 7.11 & 36.2 & 7.68 & 44.4 & 9.66 & 45.3 \\
\hline Nonferrousmetal ingots & 9.25 & 46.9 & 6.74 & 31.4 & 7.23 & 42.7 & 9.22 & 32.1 \\
\hline Average direct primary energy intensity (168 sectars) & 5.57 & & 5.24 & & 4.56 & & 4.02 & \\
\hline
\end{tabular}

Most direct energy intensive non-energy sectors are characterized by relatively high shares of direct energy intensities in the total energy intensities. However, the majority of sectors studied have a very high share of indirect energy intensity in the total energy intensity. More than 70\% (from 117 out of 161 for 2000 to 129 out of 161 for 1995) of non-energy sectors had such a share higher than $60 \%$. Average indirect energy intensities of non-energy sectors were more than twice as high as direct ones as shown in Table 8. This highlights the importance of indirect 
and total energy intensities, for instance, for energy conservation policies. $<$ Table 8> Average total, direct \& indirect energy intensities in Korea (1995-2010).

\begin{tabular}{|c|c|c|c|c|c|c|c|c|c|}
\hline & & & \multirow{2}{*}{$\begin{array}{c}1995 \\
\mathrm{~kJ} / \text { Won }\end{array}$} & \multirow{2}{*}{$\begin{array}{c}2000 \\
\mathrm{~kJ} / \mathrm{Won}\end{array}$} & \multirow{2}{*}{$\begin{array}{c}2005 \\
\mathrm{~kJ} / \mathrm{Won}\end{array}$} & \multirow{2}{*}{$\begin{array}{c}2009 \\
\mathrm{~kJ} / \text { Won }\end{array}$} & \multirow{2}{*}{$\begin{array}{c}2010 \\
\mathrm{~kJ} / \mathrm{Won}\end{array}$} & \multicolumn{2}{|c|}{ Annual growth \% } \\
\hline & & & & & & & & $1995-2000$ & $2000-2009$ \\
\hline \multicolumn{3}{|c|}{ In current prices (total) } & 28.28 & 20.80 & 15.32 & 13.69 & 11.81 & -5.96 & -4.54 \\
\hline$"$ & $"$ & (direct) & 9.02 & 6.65 & 4.56 & 3.22 & 2.96 & -5.91 & -7.74 \\
\hline$"$ & $"$ & (indirect) & 19.26 & 14.15 & 10.76 & 10.47 & 8.85 & -5.98 & -3.29 \\
\hline \multicolumn{3}{|c|}{ In 2005 constant prices (total) } & 20.14 & 17.81 & 15.32 & 16.75 & & -2.43 & -0.68 \\
\hline$"$ & $"$ & (direct) & 5.57 & 5.24 & 4.56 & 4.02 & & -1.21 & -2.90 \\
\hline " & " & (indirect) & 14.57 & 12.57 & 10.76 & 12.73 & & -2.91 & 0.14 \\
\hline
\end{tabular}

Notes: Total carbon intensity means direct and indirect energy intensity.

The exchange rate was 1024.13 Won per USD 1 or 97.6 Cents per 1000 Won in 2005.

$<$ Table 9> Total (direct and indirect) energy intensities of most intensive non-energy sectors in Korea.

\begin{tabular}{lcccccccc}
\hline & \multicolumn{2}{c}{1995} & \multicolumn{2}{c}{2000} & \multicolumn{2}{c}{2005} & \multicolumn{2}{c}{2009} \\
\hline & \multicolumn{2}{c}{$\mathrm{kJ} / \mathrm{Won}_{2005}$} & \multicolumn{2}{c}{$\mathrm{kJ} / \mathrm{Won}_{2005}$} & \multicolumn{2}{c}{$\mathrm{kJ} / \mathrm{Won}_{2005}$} & \multicolumn{2}{c}{$\mathrm{kJ} / \mathrm{Won}_{2005}$} \\
& Intensity & rank & Intensity & rank & Intensity & rank & Intensity & rank \\
\hline Petrochemical basic products & 106.99 & 2 & 87.91 & 2 & 107.75 & 1 & 111.18 & 1 \\
Synthetic resins & 83.44 & 4 & 62.27 & 4 & 63.21 & 5 & 78.76 & 2 \\
Chemical fibers & 80.61 & 7 & 48.38 & 7 & 51.33 & 6 & 75.86 & 3 \\
Synthetic rubber & 81.51 & 6 & 61.27 & 6 & 74.05 & 3 & 68.79 & 4 \\
Pig iron and ferroalloys & 95.68 & 3 & 79.84 & 3 & 43.30 & 8 & 65.44 & 5 \\
Other industrial organic basic chemical products & 107.70 & 1 & 67.49 & 1 & 74.64 & 2 & 65.41 & 6 \\
Steel ingots and semi-finished products & 74.03 & 8 & 64.80 & 8 & 36.06 & 10 & 51.18 & 7 \\
Misc. chemical products & 40.41 & 18 & 32.36 & 18 & 33.50 & 12 & 47.98 & 8 \\
Iron and steel foundries and forgings & 49.47 & 11 & 49.41 & 11 & 27.93 & 19 & 44.10 & 9 \\
Dyes, pigments, and paints & 38.49 & 21 & 38.86 & 21 & 34.03 & 11 & 43.84 & 10 \\
Hot rolled steel products & 51.30 & 9 & 46.78 & 9 & 28.30 & 18 & 39.34 & 11 \\
Fiber yarn & 31.60 & 25 & 29.65 & 25 & 32.00 & 14 & 37.93 & 12 \\
Fertilizers and pesticides & 47.20 & 13 & 37.27 & 13 & 25.43 & 22 & 36.66 & 13 \\
Plastic products & 48.16 & 12 & 38.47 & 12 & 30.63 & 15 & 36.56 & 14 \\
Fiber fabrics & 33.40 & 22 & 26.65 & 22 & 27.50 & 20 & 34.03 & 15 \\
\hline Average energy intensity (168 sectors) & 20.14 & & 17.81 & & 15.32 & & 16.75 \\
\hline
\end{tabular}

Note: The exchange rate was 1024.13 Won per USD 1 or 97.6 Cents per 1000 Won in 2005.

Total energy intensities in 2005 constant deflated prices for the period from 1995 to 2009 in Table 9 reveal again that iron \& steel and chemical products (sectors) are most energy intensive. The average total energy intensity decreased from 1995 to 2005 but increased from 2005 to 2009 as was the case for the average direct 
energy intensity. As the energy consumption depend not only on the energy intensity (energy efficiency) but also on the amount of household consumption of goods and services, it is necessary to have a look at the household consumption expenditure (categories).

$<$ Table 10> Largest consumption expenditure categories of Korean households (1995-2009).

\begin{tabular}{|c|c|c|c|c|c|c|c|c|c|c|c|c|}
\hline & \multicolumn{3}{|c|}{1995} & \multicolumn{3}{|c|}{2000} & \multicolumn{3}{|c|}{2005} & \multicolumn{3}{|c|}{2009} \\
\hline & $\begin{array}{c}\text { Consumption } \\
\text { Share }(\%)\end{array}$ & $\begin{array}{c}\text { Intensity } \\
\mathrm{k} J / \mathrm{Won}_{2005}\end{array}$ & Rank & $\begin{array}{c}\text { Consumption } \\
\text { Share }(\%)\end{array}$ & $\begin{array}{l}\text { Intensity } \\
\mathrm{kJ} / \mathrm{Won}_{2005}\end{array}$ & Rank & $\begin{array}{c}\text { Consumption } \\
\text { Share (\%) }\end{array}$ & $\begin{array}{c}\text { Intensity } \\
\mathrm{kJ} / \mathrm{Won}_{2005}\end{array}$ & Rank & $\begin{array}{c}\text { Consumption } \\
\text { Share }(\%)\end{array}$ & $\begin{array}{l}\text { Intensity } \\
\mathrm{kJ} / \mathrm{Won}_{2005}\end{array}$ & Rank \\
\hline Real estate & 8.29 & 6.00 & 2 & 13.88 & 4.30 & 1 & 1321 & 4.30 & 1 & 12.80 & 5.40 & 1 \\
\hline Wholesale and retail trade & 1026 & 733 & 1 & 752 & 5.63 & 2 & 8.14 & 5.63 & 2 & 8.03 & 6.85 & 2 \\
\hline Education & 6.93 & 2.87 & 3 & 620 & 3.45 & 5 & 7.39 & 3.45 & 4 & 7.77 & 6.15 & 3 \\
\hline Eating and drinking places & 6.35 & 11.04 & 4 & 721 & 8.37 & 4 & 7.53 & 8.37 & 3 & 7.61 & 839 & 4 \\
\hline Medical and health services & 5.84 & 621 & 5 & 7.43 & 6.29 & 3 & 4.73 & 6.29 & 5 & 4.90 & 6.89 & 5 \\
\hline Insurance & 3.53 & 426 & 8 & 292 & 3.96 & 10 & 3.47 & 3.96 & 7 & 4.13 & 4.70 & 6 \\
\hline Financial services & 1.85 & 3.05 & 14 & 3.19 & 2.30 & 8 & 2.98 & 2.30 & 9 & 3.89 & 231 & 7 \\
\hline Postal service and telecommunication & 1.12 & 6.32 & 23 & 3.03 & 4.63 & 9 & 4.22 & 4.63 & 6 & 3.20 & 520 & 8 \\
\hline Amusement and spats activities & 1.63 & 923 & 15 & 198 & 6.18 & 13 & 3.41 & 6.18 & 8 & 3.19 & 5.53 & 9 \\
\hline Textile wearing apparels andaccessores & 1.62 & 17.84 & 16 & 1.15 & 1648 & 21 & 2.26 & 1648 & 13 & 256 & 10.10 & 10 \\
\hline Roadtranspat & 5.15 & 20.64 & 7 & 3.41 & 14.68 & 7 & 2.75 & 14.68 & 11 & 244 & 12.91 & 11 \\
\hline Motor vahicles and motor veh icle equ ipment & 1.94 & 19.56 & 13 & 1.77 & 17.30 & 14 & 2.36 & 17.30 & 12 & 2.41 & 13.13 & 12 \\
\hline Personal sarvices & 2.09 & 690 & 11 & 2.10 & 7.77 & 12 & 1.97 & 7.77 & 14 & 201 & 8.66 & 13 \\
\hline Vegetablesand frits & 2.97 & 926 & 9 & 2.14 & 7.96 & 11 & 1.70 & 7.96 & 15 & 1.61 & 9.71 & 14 \\
\hline Repair services & 1.18 & 14.99 & 20 & 155 & 13.75 & 17 & 1.65 & 13.75 & 16 & 1.57 & 12.51 & 15 \\
\hline Communications and broadcasting equipment & 0.23 & 19.58 & 61 & 0.80 & 14.96 & 27 & 1.15 & 14.96 & 21 & 1.56 & 932 & 16 \\
\hline Tobacco products & 2.18 & 1.56 & 10 & 152 & 1.60 & 18 & 1.28 & 1.60 & 18 & 1.32 & 224 & 17 \\
\hline Socil work activities & 0.29 & 4.79 & 58 & 0.52 & 6.43 & 37 & 1.04 & 6.43 & 25 & 1.27 & 6.46 & 18 \\
\hline Social organizations & 0.85 & 720 & 27 & 1.05 & 7.28 & 23 & 1.29 & 7.28 & 17 & 1.24 & 6.53 & 19 \\
\hline Cosmetics soap, and other toilet preperations & 1.02 & 22.62 & 24 & 0.90 & 1816 & 25 & 1.04 & 1816 & 26 & 1.14 & 16.17 & 20 \\
\hline 20 hrgest consumption categories & 6532 & 10.06 & & 70.28 & 8.58 & & 73.56 & 8.58 & & 74.64 & 7.96 & \\
\hline Other consumption categories (148 sectas) & 34.68 & 21.50 & & 29.72 & 19.06 & & 26.44 & 16.23 & & 25.36 & 17.94 & \\
\hline Average total energy intensity ( 168 sectors) & & 20.14 & & & 17.81 & & & 15.32 & & & 16.75 & \\
\hline
\end{tabular}

Table 10 shows shares of the 20 largest sectoral household consumption expenditure categories. These shares amounted to $65.32 \%$ of the total household consumption expenditure in 1995, more than $70 \%$ in the years 2000, 2005 and 2009. The main expenditure for non-energy sectors had relatively low total energy intensities except road transport, motor vehicle and motor vehicle equipment and communications and broadcasting equipment. Real estate (housing rental), postal service and telecommunication, financial services and insurance recorded increases in the share in the total household consumption expenditure, a sign of increasing living standards. However, this share decreased in the case of wholesale \& retail trade and medical and health. 


\section{Direct energy consumption of households}

The direct energy consumption of Korean households accounted for $14.6 \%$ (2005) to $17.2 \%$ (2000) of the total energy consumption. Direct household energy consumption grew at an annual average rate of $6.3 \%$ in the second half of the $1990 \mathrm{~s}$ and slowed down to $1.6 \%$ in the 2000 s as shown in Table 11 . The per capita direct household energy consumption increased from 22.24 GJ in 1995 to 32.19 GJ in 2009. The consumption of oil products was mainly responsible for the direct household energy consumption in 1995. Oil products were main household fuels in the 1990s. As oil products were replaced by natural gas as heating fuel and as more and more electricity is used in households for heating, cooling and operation of electrical appliances, electricity consumption became the main source of direct household energy consumption in Korea.

The oil products share in the direct household energy consumption decreased from $65.7 \%$ in 1995 to $24.8 \%$ in 2009 , while the electricity share increased from $21.9 \%$ to $52.6 \%$ in the same period. The share of the town gas and steam \& district heat sector increased, too. The coal share decreased until 2000 as coal briquette consumption for heating and cooking was replaced by town gas and district heat with growing income. It increased in the 2000s as heavily subsidized coal briquettes became heating and cooking fuel for very low-income households. 
<Table 11> Direct energy consumption of Korean households by fuel (1995-2010).

\begin{tabular}{|c|c|c|c|c|c|c|}
\hline & \multirow{2}{*}{$\begin{array}{c}1995 \\
\text { PJ }\end{array}$} & \multirow{2}{*}{$\begin{array}{c}2000 \\
\text { PJ }\end{array}$} & \multirow{2}{*}{$\begin{array}{c}2005 \\
\text { PJ }\end{array}$} & \multirow{2}{*}{$\begin{array}{c}2009 \\
\text { PJ }\end{array}$} & \multicolumn{2}{|c|}{ Annual growth rate in $\%$} \\
\hline & & & & & $1995-2000$ & $2000-2009$ \\
\hline Oil product & $\begin{array}{r}659.30 \\
(65.7)\end{array}$ & $\begin{array}{r}605.17 \\
(44.5)\end{array}$ & $\begin{array}{r}408.41 \\
(31.7)\end{array}$ & $\begin{array}{r}388.64 \\
(24.8)\end{array}$ & -1.7 & -4.8 \\
\hline Other oil product & $\begin{array}{l}14.04 \\
(1.40)\end{array}$ & $\begin{array}{l}0.44 \\
(0.03)\end{array}$ & $\begin{array}{c}0.25 \\
(0.02)\end{array}$ & $\begin{array}{c}0.16 \\
(0.01)\end{array}$ & -50.0 & -10.9 \\
\hline Coal & $\begin{array}{r}23.39 \\
(2.3)\end{array}$ & $\begin{array}{l}9.06 \\
(0.7)\end{array}$ & $\begin{array}{r}10.77 \\
(0.8)\end{array}$ & $\begin{array}{r}15.13 \\
(1.0)\end{array}$ & -17.3 & 5.9 \\
\hline Electricity & $\begin{array}{r}219.23 \\
(21.9)\end{array}$ & $\begin{array}{r}407.24 \\
(30.0)\end{array}$ & $\begin{array}{r}539.01 \\
(41.9)\end{array}$ & $\begin{array}{r}825.17 \\
(52.6)\end{array}$ & 13.2 & 8.2 \\
\hline Town gas & $\begin{array}{r}69.05 \\
(6.9)\end{array}$ & $\begin{array}{r}283.03 \\
(20.8)\end{array}$ & $\begin{array}{r}265.96 \\
(20.7)\end{array}$ & $\begin{array}{r}250.16 \\
(15.9)\end{array}$ & 32.6 & -1.4 \\
\hline Steam \& heat & $\begin{array}{r}17.82 \\
(1.8)\end{array}$ & $\begin{array}{r}53.72 \\
(4.0)\end{array}$ & $\begin{array}{r}63.02 \\
(4.9)\end{array}$ & $\begin{array}{r}90.01 \\
(5.7)\end{array}$ & 24.7 & 5.9 \\
\hline Total direct & $\begin{array}{r}1002.83 \\
(100.0) \\
\end{array}$ & $\begin{array}{r}1358.66 \\
(100.0) \\
\end{array}$ & $\begin{array}{r}1287.43 \\
(100.0) \\
\end{array}$ & $\begin{array}{r}1569.27 \\
(100.0) \\
\end{array}$ & 6.3 & 1.6 \\
\hline \multicolumn{7}{|c|}{ Estimation of energy requirement without price differentiati on betw een households and industry } \\
\hline Oil product & 800.20 & 735.45 & 504.22 & 477.99 & & \\
\hline Electricity & 360.55 & 600.74 & 754.34 & 1015.26 & & \\
\hline Total direct & 1285.06 & 1682.45 & 1598.56 & 1848.55 & & \\
\hline \multicolumn{7}{|c|}{ Per capita direct household energy con sumption (GJ) } \\
\hline & 22.24 & 28.90 & 26.74 & 32.19 & 5.4 & 1.2 \\
\hline \multicolumn{7}{|c|}{ Share of direct househ old energ y consumption in the country' total in \% } \\
\hline & 16.5 & 17.2 & 14.6 & 16.4 & & \\
\hline \multicolumn{7}{|c|}{ Share of direct energy purchase in the hous ehold expenditure in \% } \\
\hline & 7.3 & 7.4 & 5.2 & 5.1 & & \\
\hline
\end{tabular}

Table 11 shows the estimation of direct household energy consumption with price differentiation between households and industries. As discussed before, uniform prices for households and the industry applied to convert monetary into energy input-output table result in an increase of household energy consumption and concomitantly higher household energy consumption. It is common that the industry pays fuels less than households. With the price differentiation between households and industries the energy consumption due to oil products and electricity consumption decreased from 477.99 PJ to $388.64 \mathrm{PJ}$ and from 1015.26 PJ to 1569.27 PJ, respectively in 2009. The direct household energy consumption decreased by $15.1 \%$ from 1848.55 PJ to 1569.27 PJ in 2009. It is important to differentiate fuel prices between households and industries. 


\section{Indirect energy consumption of households}

More than $69 \%$ of the total energy consumption of households was indirect in the 1995 to 2009 period as shown in Table 12. Indirect energy consumption of households were high as goods and services consumed were produced energy intensively by industries due to relatively low priced fuel oil, coal and electricity. There is hardly any tax on coal and electricity is sold below production costs. Taxes on fuel oil are very low compared to oil products used by households such as gasoline, diesel and LPG.

Direct energy consumption of Korean households were low because relatively high prices for gasoline (high gasoline taxes) and electricity (high progressive tariffs only for households as can be seen in Table 13) discouraged household energy use, hence energy consumption. Moreover, Table 8 shows that the per capita primary energy consumption of Korean households (direct household energy consumption less fuel consumption for private cars, as used in the conventional energy statistics) was the lowest among countries in comparison, while their per capita energy consumption of the whole economy was much higher than that of Japan, France and Germany in 2010.

Another reason for the high share of indirect household energy consumption could be found in a relatively high share of iron \& steel and petrochemical industries in Korea as shown in Table 5. Per capita energy consumptions of iron $\&$ steel and petrochemical industries were with 0.214 toe $(8.96 \mathrm{GJ})$ and 0.785 toe (32.87 GJ), respectively highest among OECD countries in comparison. Indirect energy consumption of households did not change in the second half of the 1990s. Indirect household energy consumption grew by $3.3 \%$ in the 2000 s. Again higher electricity consumption was mainly responsible for the increase in indirect household energy consumption in 2009. 
<Table 12> Indirect energy consumption of Korean households by fuel (1995-2009).

\begin{tabular}{|c|c|c|c|c|c|c|}
\hline & \multirow{2}{*}{$\begin{array}{c}1995 \\
\text { PJ }\end{array}$} & \multirow{2}{*}{$\begin{array}{c}2000 \\
\text { PJ }\end{array}$} & \multirow{2}{*}{$\begin{array}{c}2005 \\
\text { PJ }\end{array}$} & \multirow{2}{*}{$\begin{array}{c}2009 \\
\text { PJ }\end{array}$} & \multicolumn{2}{|c|}{ Anmual growth rate in $\%$} \\
\hline & & & & & $1995-2000$ & $2000-2009$ \\
\hline \multirow[t]{2}{*}{ Naphtha } & 590.74 & 488.46 & 634.03 & 967.28 & -3.7 & 7.9 \\
\hline & $(20.1)$ & $(15.8)$ & $(17.8)$ & $(23.4)$ & & \\
\hline \multirow[t]{2}{*}{ Oil products } & 1271.87 & 863.56 & 768.03 & 685.43 & -7.5 & -25 \\
\hline & $(43.3)$ & $(28.0)$ & $(21.6)$ & $(16.6)$ & & \\
\hline \multirow[t]{2}{*}{ Other oil products } & 34.65 & 63.94 & 49.08 & 42.11 & 13.0 & -4.5 \\
\hline & $(1.18)$ & $(207)$ & (1.38) & $(1.02)$ & & \\
\hline \multirow[t]{2}{*}{ Coal } & 133.17 & 205.47 & 135.24 & 224.58 & 9.1 & 1.0 \\
\hline & $(4.5)$ & $(6.7)$ & (3.8) & $(5.4)$ & & \\
\hline \multirow[t]{2}{*}{ Electriaty } & 827.20 & 1256.97 & 1625.71 & 1811.54 & 8.7 & 4.1 \\
\hline & $(28.1)$ & $(40.8)$ & $(45.8)$ & $(43.8)$ & & \\
\hline \multirow[t]{2}{*}{ Town gas } & 67.16 & 132.31 & 248.91 & 320.56 & 14.5 & 10.3 \\
\hline & (2.3) & $(4.3)$ & $(7.0)$ & $(7.7)$ & & \\
\hline \multirow[t]{2}{*}{ S team \& heat } & 14.50 & 72.99 & 91.78 & 85.28 & 38.2 & 1.7 \\
\hline & $(14.5)$ & $(73.0)$ & $(91.8)$ & $(85.3)$ & & \\
\hline \multirow[t]{2}{*}{ Total indirect } & 2939.30 & 3083.71 & 355278 & 4136.77 & 1.0 & 3.3 \\
\hline & $(100.0)$ & $(100.0)$ & $(100.0)$ & $(100.0)$ & & \\
\hline \multicolumn{7}{|c|}{ Estimation of energy consumption w ithout price differentiation between households and industry } \\
\hline Oil products & 1187.46 & 807.28 & 729.38 & 648.46 & & \\
\hline Electricity & 755.80 & 1158.89 & 1516.78 & 1714.51 & & \\
\hline Total indiriect & 2783.50 & 2929.35 & 3405.20 & 4002.63 & & \\
\hline \multicolumn{7}{|c|}{ Per capita indirect hous ehold energy consumption (GJ) } \\
\hline & 65.18 & 65.60 & 73.80 & 84.86 & 0.1 & 2.9 \\
\hline \multicolumn{7}{|c|}{ Share of indirect energy consumption in the households' total in \% } \\
\hline & 74.6 & 69.4 & 73.4 & 72.5 & & \\
\hline \multicolumn{7}{|c|}{ Share of indirect household energy consumption in the country' total in \% } \\
\hline & 48.5 & 39.1 & 40.4 & 43.1 & & \\
\hline \multicolumn{7}{|c|}{ Share of indirect energy purchase in the household expenditure in \% } \\
\hline & 13.1 & 10.0 & 9.2 & 9.1 & & \\
\hline
\end{tabular}

Notes: Figures in brackets are shares in the ind irect househ old energy consumption in \% Oil prod ucts are gasol ine, diesel, kerosene, fuel oil, av iation fuel, fuel oil LPG etc. Other products are lubricants, solvent, paraffin waxes etc.

It is interesting to note that the price differentiation in the development of energy input-output tables, hence readjusting uniform prices to more realistic price differentiation between households and industries, resulted in higher indirect household energy consumption as shown in Table 12. The indirect household energy consumption after price differentiation grew by $3.6 \%$ from $4002.63 \mathrm{PJ}$ to 4136.77 PJ in 2009. The direct household energy consumption decreased while the indirect household energy consumption increased. 
$<$ Table 13> Monthly electricity tariffs in Korea as of August 2010.

\begin{tabular}{|c|c|c|c|c|c|}
\hline \multicolumn{2}{|c|}{$\begin{array}{l}\text { Basic tariffs per month }{ }^{\text {a) }} \\
\text { (Won/month \& household) }\end{array}$} & \multicolumn{4}{|c|}{$\begin{array}{l}\text { Working tariffs }{ }^{\text {b) }} \\
\text { (Won per kWh) }\end{array}$} \\
\hline & & & & Using upto & Cumulative \\
\hline Up to $100 \mathrm{kWh}$ & 380 & Up to $100 \mathrm{kWh}$ & 56.20 & $100 \mathrm{kWh}$ & 56.20 \\
\hline $101-200 \mathrm{kWh}$ & 840 & $101-200 \mathrm{kWh}$ & 116. 10 & $200 \mathrm{kWh}$ & 86.15 \\
\hline $201-300 \mathrm{kWh}$ & 1,460 & $201-300 \mathrm{kWh}$ & 171.60 & $300 \mathrm{kWh}$ & 114.63 \\
\hline $301-400 \mathrm{kWh}$ & 3,490 & $301-400 \mathrm{kWh}$ & 253.60 & $400 \mathrm{kWh}$ & 149.38 \\
\hline $401-500 \mathrm{kWh}$ & 6,540 & $401-500 \mathrm{kWh}$ & 373.70 & $500 \mathrm{kWh}$ & 194.24 \\
\hline \multirow[t]{5}{*}{ More than $500 \mathrm{kWh}$} & 11,990 & More than $500 \mathrm{kWh}$ & 656.20 & $600 \mathrm{kWh}$ & 271.23 \\
\hline & & & & $700 \mathrm{kWh}$ & 326.23 \\
\hline & & & & $800 \mathrm{kWh}$ & 367.48 \\
\hline & & & & $900 \mathrm{kWh}$ & 399.56 \\
\hline & & & & $1000 \mathrm{kWh}$ & 425.22 \\
\hline
\end{tabular}

Source: Kor ea Electric Power Corporation (KEPCO)

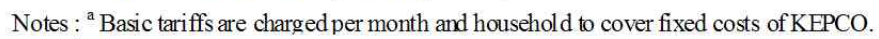

${ }^{\mathrm{b}}$ Working tariffs are highly progressive with the electricity consumedin a month.

Average exchange rate in 2010: Won 1156.26/USD.

\section{Total energy consumption of households}

Total (direct and indirect) household energy consumption increased from 3942.12 PJ in 1995 to 5706.05 PJ in 2009. The growth rate was a little higher in the 2000s as shown in Table 14. As households were responsible for about between $55 \%$ in 2005 and $65 \%$ in 1995 of the energy consumption in Korea, they should be the main policy target for energy conservation. The rest of the energy consumption was emitted by the government (7.2\%), the public (5.3\%) and private $(20.7 \%)$ investments $(26 \%)$, the net exports $(10.6 \%)$ being the difference between exports and imports and stock exchange (0.9\%) in 2005. Households did not realize how much they emitted energy directly and indirectly as their direct energy purchase accounted only to from $5.1 \%$ in 2009 to $7.4 \%$ in 2000 of their consumption expenditures.

Total household energy consumption in spite of using low energy intensive electricity grew fast in the 1995 to 2009 period due to low electricity tariffs especially for industries. The consumption of oil products decreased substantially as relatively expensive oil products were replaced by electricity, town gas and steam 
$\&$ district heat. Energy consumption by coal grew also because the shares of coal using iron \& steel and cement industries increased. This was also the case for naphtha, the basic feedstock for the petrochemical industry.

Table 14 shows that the estimation of total energy consumption without price differentiation between households and industries is bigger than those with price differentiation. For the year 2009 households consumed energy in the amount of 5706.05 PJ against 5851.18 PJ without price differentiation. In 2009 electricity consumption became the largest energy source for household energy consumption, as households consumed much more electricity (4230.4 PJ) than petroleum products (2003.8 PJ) indirectly.4)

$<$ Table 14> Total energy consumption of Korean households by fuel (1995-2009).

\begin{tabular}{|c|c|c|c|c|c|c|}
\hline & 1995 & 2000 & 2005 & 2009 & \multicolumn{2}{|c|}{ Annual growth rate in $\%$} \\
\hline & PJ & PJ & PJ & PJ & $1995-2000$ & $2000-2009$ \\
\hline \multirow[t]{2}{*}{ Naphtha } & 590.74 & 488.46 & 634.03 & 967.28 & -3.7 & 7.9 \\
\hline & $(15.0)$ & $(11.0)$ & $(13.1)$ & $(17.0)$ & & \\
\hline \multirow[t]{2}{*}{ Oil products } & 1931.16 & 1468.73 & 1176.45 & 1074.07 & -5.3 & -3.4 \\
\hline & $(49.0)$ & $(33.1)$ & $(24.3)$ & $(18.8)$ & & \\
\hline \multirow[t]{2}{*}{ Other oil products } & 48.70 & 64.38 & 49.33 & 42.26 & 5.7 & -4.6 \\
\hline & (1.24) & $(1.45)$ & $(1.02)$ & $(0.74)$ & & \\
\hline \multirow[t]{2}{*}{ Coal } & 156.56 & 214.53 & 146.02 & 239.70 & 6.5 & 1.2 \\
\hline & $(4.0)$ & $(4.8)$ & $(3.0)$ & $(4.2)$ & & \\
\hline \multirow[t]{2}{*}{ Electricity } & 1046.43 & 1664.22 & 2164.72 & 2636.71 & 9.7 & 5.2 \\
\hline & $(26.5)$ & $(37.5)$ & $(44.7)$ & $(46.2)$ & & \\
\hline \multirow[t]{2}{*}{ Town gas } & 136.21 & 415.34 & 514.87 & 570.72 & 25.0 & 3.6 \\
\hline & $(3.5)$ & (9.3) & $(10.6)$ & $(10.0)$ & & \\
\hline \multirow[t]{2}{*}{ S team \& heat } & 32.32 & 126.72 & 154.80 & 175.29 & 31.4 & 3.7 \\
\hline & $(0.8)$ & (2.9) & (3.2) & (3.1) & & \\
\hline \multirow[t]{2}{*}{ Total households } & 3942.12 & 4442.37 & 4840.21 & 5706.05 & 2.4 & 2.8 \\
\hline & $(100.0)$ & $(100.0)$ & $(100.0)$ & $(100.0)$ & & \\
\hline \multicolumn{7}{|c|}{ Estimation of energy consumption without price differentiation between hou seholds and industry } \\
\hline \multicolumn{7}{|c|}{$\begin{array}{lllll}\text { Oil products } & 1987.66 & 1542.74 & 1233.59 & 1126.45\end{array}$} \\
\hline Electricity & 1116.36 & 1759.63 & 2271.12 & 2729.77 & & \\
\hline Total households & 4068.56 & 4611.80 & 5003.76 & 5851.18 & & \\
\hline \multicolumn{7}{|c|}{ Per capita to tal househ old energy consumption (PJ) } \\
\hline & 87.42 & 94.50 & 100.55 & 117.05 & 1.6 & 2.4 \\
\hline \multicolumn{7}{|c|}{$\mathrm{S}$ hares of to tal en ergy purchase in the household expen diture in $\%$} \\
\hline & 20.4 & 17.4 & 14.5 & 14.1 & & \\
\hline \multicolumn{7}{|c|}{ S hares of to tal household energy consumption in the country' total in \% } \\
\hline & 65.0 & 56.4 & 55.0 & 59.5 & & \\
\hline
\end{tabular}

4) $34.1 \%$ of electricity was produced in 2009 by nuclear, $44.6 \%$ by coal, $15.1 \%$ by LNG, $3.2 \%$ by heavy oil and diesel, $1.3 \%$ by hydro and $2.6 \%$ by renewable energy and others. 
Table 15 reveals changes in household energy emission patterns in Korea from 1985 to 2009. Consumption groups like living, education, leisure and banking \& insurance experienced an increase in their share of the household energy consumption. Consumption groups like food \& beverage, clothing \& footwear, hygiene \& medicare, transport \& communication and household recorded a decrease in the share in the household energy consumption. In terms of direct household energy consumption, electricity, town gas and steam \& district heat play a more important role than other fuels. All these changes are related to the increasing living standards and rapid economic growth in Korea.

$<$ Table 15> Energy consumption patterns of Korean households (1995-2009).

\begin{tabular}{|c|c|c|c|c|c|}
\hline & $\begin{array}{c}1995 \\
\text { PJ }\end{array}$ & $\begin{array}{c}2000 \\
\text { PJ }\end{array}$ & $\begin{array}{c}2005 \\
\text { PJ }\end{array}$ & $\begin{array}{c}2009 \\
\text { PJ }\end{array}$ & $\begin{array}{c}2010 \\
\text { PJ }\end{array}$ \\
\hline \multicolumn{6}{|l|}{ Indirect energy } \\
\hline F od \& bev erage & $\begin{array}{l}546.2 \\
(14.1)\end{array}$ & $\begin{array}{l}568.8 \\
(12.8)\end{array}$ & $\begin{array}{l}615.4 \\
(12.7)\end{array}$ & $\begin{array}{l}689.9 \\
(120)\end{array}$ & $\begin{array}{l}666.7 \\
(12.0)\end{array}$ \\
\hline Clothing \& footwear & $\begin{array}{r}158.7 \\
(4.1)\end{array}$ & $\begin{array}{r}126.8 \\
(2.8)\end{array}$ & $\begin{array}{r}216.7 \\
(4.5)\end{array}$ & $\begin{array}{r}224.8 \\
(3.9)\end{array}$ & $\begin{array}{r}225.1 \\
(4.0)\end{array}$ \\
\hline Household & $\begin{array}{r}288.7 \\
(7.5)\end{array}$ & $\begin{array}{r}336.3 \\
(7.5)\end{array}$ & $\begin{array}{r}324.2 \\
(6.7)\end{array}$ & $\begin{array}{r}364.9 \\
(6.4)\end{array}$ & $\begin{array}{r}388.2 \\
(7.0)\end{array}$ \\
\hline Living & $\begin{array}{r}182.2 \\
(4.7)\end{array}$ & $\begin{array}{r}256.9 \\
(5.8)\end{array}$ & $\begin{array}{r}342.5 \\
(7.1)\end{array}$ & $\begin{array}{r}407.8 \\
(7.1)\end{array}$ & $\begin{array}{r}370.2 \\
(6.7)\end{array}$ \\
\hline Transport \& commun ication & $\begin{array}{l}482.4 \\
(12.5)\end{array}$ & $\begin{array}{r}429.6 \\
(9.6)\end{array}$ & $\begin{array}{l}496.7 \\
(10.2)\end{array}$ & $\begin{array}{r}531.5 \\
(9.3)\end{array}$ & $\begin{array}{r}478.9 \\
(8.6)\end{array}$ \\
\hline Education & $\begin{array}{l}61.7 \\
(1.6)\end{array}$ & $\begin{array}{l}84.2 \\
(1.9)\end{array}$ & $\begin{array}{r}173.5 \\
(3.6)\end{array}$ & $\begin{array}{r}2526 \\
(4.4)\end{array}$ & $\begin{array}{r}242.4 \\
(4.4)\end{array}$ \\
\hline Hyg iene \& medicare & $\begin{array}{r}184.7 \\
(4.8)\end{array}$ & $\begin{array}{r}220.8 \\
(5.0)\end{array}$ & $\begin{array}{r}205.9 \\
(4.2)\end{array}$ & $\begin{array}{r}269.5 \\
(4.7)\end{array}$ & $\begin{array}{r}262.3 \\
(4.7)\end{array}$ \\
\hline Leisure & $\begin{array}{r}122.6 \\
(3.2)\end{array}$ & $\begin{array}{r}149.1 \\
(3.3)\end{array}$ & $\begin{array}{r}239.4 \\
(4.9)\end{array}$ & $\begin{array}{r}221.9 \\
(3.9)\end{array}$ & $\begin{array}{r}230.1 \\
(4.1)\end{array}$ \\
\hline Banking \& in surance & $\begin{array}{l}61.4 \\
(1.6)\end{array}$ & $\begin{array}{l}75.7 \\
(1.7)\end{array}$ & $\begin{array}{r}101.7 \\
(2.1)\end{array}$ & $\begin{array}{r}163.3 \\
(2.8)\end{array}$ & $\begin{array}{r}143.9 \\
(26)\end{array}$ \\
\hline Other consumption & $\begin{array}{l}521.2 \\
(25.2)\end{array}$ & $\begin{array}{l}495.8 \\
(30.3)\end{array}$ & $\begin{array}{l}599.7 \\
(26.3)\end{array}$ & $\begin{array}{l}748.0 \\
(27.2)\end{array}$ & $\begin{array}{l}756.7 \\
(25.9)\end{array}$ \\
\hline Total of indirect en ergy & $\begin{array}{r}2939.3 \\
(74.8)\end{array}$ & $\begin{array}{r}3083.7 \\
(69.7)\end{array}$ & $\begin{array}{r}35528 \\
(73.7)\end{array}$ & $\begin{array}{r}4136.8 \\
(72.8)\end{array}$ & $\begin{array}{r}9158.8 \\
(74.1)\end{array}$ \\
\hline \multicolumn{6}{|l|}{ Direct energy } \\
\hline Coal & $\begin{array}{l}23.4 \\
(0.9)\end{array}$ & $\begin{array}{l}9.1 \\
(0.2)\end{array}$ & $\begin{array}{l}10.8 \\
(0.3)\end{array}$ & $\begin{array}{l}15.1 \\
(0.4)\end{array}$ & $\begin{array}{l}9.5 \\
(0.2)\end{array}$ \\
\hline Petroleum & $\begin{array}{l}673.3 \\
(16.9)\end{array}$ & $\begin{array}{l}605.6 \\
(13.5)\end{array}$ & $\begin{array}{r}408.7 \\
(8.4)\end{array}$ & $\begin{array}{r}388.8 \\
(6.7)\end{array}$ & $\begin{array}{r}360.6 \\
(6.5)\end{array}$ \\
\hline Electriaty & $\begin{array}{r}219.2 \\
(5.5)\end{array}$ & $\begin{array}{r}407.2 \\
(9.1)\end{array}$ & $\begin{array}{l}539.0 \\
(11.0)\end{array}$ & $\begin{array}{l}825.2 \\
(14.3)\end{array}$ & $\begin{array}{l}748.2 \\
(13.5)\end{array}$ \\
\hline Town gas \& heat & $\begin{array}{l}86.9 \\
(2.2)\end{array}$ & $\begin{array}{r}336.8 \\
(7.5)\end{array}$ & $\begin{array}{r}329.0 \\
(6.7)\end{array}$ & $\begin{array}{r}340.2 \\
(5.9)\end{array}$ & $\begin{array}{r}323.9 \\
(5.8)\end{array}$ \\
\hline Total of directenergy & $\begin{array}{r}10028 \\
(25.2)\end{array}$ & $\begin{array}{r}1358.7 \\
(30.3)\end{array}$ & $\begin{array}{r}1287.4 \\
(26.3)\end{array}$ & $\begin{array}{r}1569.3 \\
(27.2)\end{array}$ & $\begin{array}{r}1442.1 \\
(25.9) \\
\end{array}$ \\
\hline
\end{tabular}

Note: Figures in brackets are shares in the total energy consu mption in \% 
Table 15 reveals changes in household energy emission patterns in Korea from 1985 to 2009. Consumption groups like living, education,

leisure and banking \& insurance experienced an increase in their share of the household energy consumption. Consumption groups like food \& beverage, clothing \& footwear, hygiene \& medicare, transport \& communication and household recorded a decrease in the share in the household energy consumption. In terms of direct household energy consumption, electricity, town gas and steam \& district heat play a more important role than other fuels. All these changes are related to the increasing living standards and rapid economic growth in Korea.

$<$ Table $16>$ Direct and total energy consumption by economic activity in Korea.

\begin{tabular}{lcrrrr}
\hline & Unit & \multicolumn{1}{c}{1995} & \multicolumn{1}{c}{2000} & \multicolumn{1}{c}{2005} & \multicolumn{1}{c}{2009} \\
\hline Households & PJ & 1002.83 & 1358.66 & 1287.43 & 1569.27 \\
Net exports & & -569.10 & -155.75 & -288.53 & -786.62 \\
Stodk change & & 0.49 & 123.02 & 11.92 & -384.42 \\
Direct energy consumption & PJ & 434.22 & 1325.93 & 1010.82 & 398.23 \\
\hline Households & PJ & 3942.12 & 4442.37 & 4840.21 & 5706.05 \\
Government consumption & & 406.75 & 415.40 & 643.14 & 865.38 \\
Investments & & 2467.98 & 2279.84 & 2291.97 & 2859.89 \\
Net exports & & -918.68 & 587.02 & 842.01 & 1408.56 \\
Stodk change & & 122.03 & 95.39 & 102.55 & -1355.94 \\
Total energy consumption & PJ & 6020.20 & 7820.02 & 8719.89 & 9483.94 \\
\hline Energy intensity of exports (A) & $\mathrm{kJ} /$ Won & 298.367 & 241.963 & 197.133 & 214.563 \\
Energy intensity of imports (B) & & 272.453 & 203.949 & 178.149 & 209.285 \\
Intensity ratio (A/B) & $\mathrm{B}=100$ & 109.5 & 118.6 & 110.7 & 102.5 \\
\hline
\end{tabular}

Table 16 indicates that Korean households were dominant in energy related direct and total energy consumption of the country. Investments were also important in the total energy consumption. Energy embodied exports have been larger than such imports since 2000. This is because Korea has had trade surpluses since 2000. However, Korea had more direct energy imports than direct energy exports. Korean exports were more energy intensive than imports in the studied period. This 
contradicts the expectation that an energy resource poor country like Korea should import more energy intensive goods and services and export less energy intensive goods and services, rather than vice versa. However, it was a progress that the ratio of energy intensity of exports to that of imports declined from 109.5 in 1995 and 118.6 in 2000 to 102.5 in 2009.

\section{Changes in household energy consumption}

Although the evolution in average direct, indirect and total energy intensities shown in Table 9 indicates a decrease in energy intensities (energy efficiency improvement) during the studied period, it is not clear what caused the changes in total household energy consumption. These changes (increases in household energy consumption) are related to four factors: (1) change in the household expenditure (activity effect); (2) change in the structure of household consumption (structure effect); (3) change in the energy intensity (efficiency effect) and (4) change in the energy intensity (energy efficiency) with the help of a simple decomposition analysis.

The analysis used to decompose the effects of changes in activity, structure, energy efficiency and energy efficiency on changes in energy consumption (C) is

$$
\Sigma E=\Sigma P^{*} \frac{P P I}{\Sigma P} * \frac{\Sigma E}{P P I}
$$

where $\Sigma P$ refers to household expenditure, $P P I$ (Physical production index) means here the sum of expenditure categories weighted with energy intensities of expenditure categories of a reference year, $P P I / \Sigma P$ is structure effect, $\Sigma E$ / PPI represents energy efficiency effect on consumption. Increasing PPI of PPI / $\Sigma P$ results in higher fraction and thus more energy intensive consumption structure. Whereas increasing PPI in $\Sigma E /$ PPI results in higher energy efficiency. By decomposing the differential of Eq. (7): 


$$
\Delta E=\Delta E(\text { Activity })+\Delta E(\text { Structure })+\Delta(\text { Efficiency })+\text { Residuals } .
$$

A simple average parametric Divisia method 2 (AVE-PDM2, an additive energy consumption technique) is used as to minimize the residuals (Ang, 1995).

- Activity effect:

$\Delta E($ Activity $\left.)=\left(P_{1}-P_{0}\right) *\left(\frac{P P I_{1}}{P_{1}}+\frac{P P I_{0}}{P_{0}}\right) *\left(\frac{E_{1}}{P P I_{1}}+\frac{E_{0}}{P P I_{0}}\right) / 4^{5}\right)$

- Structure effect:

$\Delta E($ Structure $)=\left(P_{1}+P_{0}\right) *\left(\frac{P P I_{1}}{P_{1}}-\frac{P P I_{0}}{P_{0}}\right) *\left(\frac{E_{1}}{P P I_{1}}+\frac{E_{0}}{P P I_{0}}\right) / 4$

- Energy efficiency effect:

$\Delta E($ Efficiency $)=\left(P_{1}+P_{0}\right) *\left(\frac{P P I_{1}}{P_{1}}+\frac{P P I_{0}}{P_{0}}\right) *\left(\frac{E_{1}}{P P I_{1}}-\frac{E_{0}}{P P I_{0}}\right) / 4$

Results of decomposition of changes in household energy consumption in periods from 1995 to 2005 are presented in Table 17. The increase in consumption expenditure (activity) was principally responsible for the rise of household energy consumption. The large positive activity effect was partly due to growing household expenditure. The household expenditures increased at an annual growth rate of 6.7\% from 283.8 TWon (Trillion Won) in 1995 to 392.3 TWon in 2000 and at an annual rate of $3.5 \%$ from 392.3 TWon in 2000 to 465.6 TWon in 2005 .

The energy efficiency (minus sign of the efficiency variable) contributed greatly to reduce the increase in total household energy consumption also in the 1995 to

5) The right side of Eqs. (9)-(11) is divided by 4 as to have the averages of the last two factors. For more discussion on the decomposition analysis see Farla et al., 1997a, b. 
2005 period. However, switching to consumption of more energy intensive goods and services (plus sign of the structure variable) caused to accelerate the increase in total household energy consumption from 1995 to 2005. There was positive efficiency but negative structure effects in the studied period.

$<$ Table 17> Decomposition of changes in total household energy consumption (PJ).

\begin{tabular}{cccccc}
\hline & $\Delta$ Energy & Activity & Structure & Efficiency & Residuals \\
\hline \multirow{2}{*}{$1995-2000$} & 500.25 & 848.78 & 390.89 & -736.00 & -3.42 \\
& $(100.0)$ & $(169.7)$ & $(78.1)$ & $(-147.1)$ & $(-0.7)$ \\
$2000-2009$ & 397.84 & 246.45 & 40.00 & 111.38 & 0.01 \\
& $(100.0)$ & $(61.9)$ & $(10.1)$ & $(28.0)$ & $(0.0)$ \\
$1995-2009$ & 898.09 & 1119.89 & 446.98 & -664.52 & -4.25 \\
& $(100.0)$ & $(124.7)$ & $(49.8)$ & $(-74.0)$ & $(-0.5)$ \\
\hline
\end{tabular}

Notes: Figures in brackets are shares in the change in the hous eholdenergy requirement in $\%$.

A minus sign means a decrease of energy consumption.

A plus sign means an increase of energy consumption.

\section{Discussion and conclusions}

\section{Discussion}

A key issue in the quantification of direct and indirect household energy consumption for the input-output analysis is to construct energy input-output tables. As detailed sectoral energy consumption and energy emission data are missing, monetary input-output tables are first converted into energy terms with the help of uniform (average) fuel prices. However, this kind of construction of energy input-output tables results in an overestimation of direct household energy consumption and concomitantly an underestimation of indirect household energy consumption. This study has tried to differentiate prices of oil products and electricity between households and industries. Better energy price information is crucial to construct energy input-output tables.

Despite a relatively disaggregated sector classification to 161 non-energy sectors 
and 7 energy sectors, sectors like vegetables and fruits, meats, diary products and wholesale and retail used in this study are too aggregated, as to make sectoral energy intensities for different years comparable. This is because large differences in energy intensities of products can exist in the same sector and because the composition of products consumed in a sector does not remain unchanged. Moreover, not only inter-sector structural changes but also intra-sector structural changes are occurring.

\section{Conclusions and recommendations}

This study converts energy consumption data given in final energy terms (TFC) into primary energy terms (TPES). Sectors with a higher share of electricity in the energy consumption tend to have lower energy intensity than those with a lower share if energy intensities are calculated in final energy terms. Moreover, this study has used differentiated prices of oil products and electricity between households and industries. Uniform (average) prices used to convert monetary to energy inputoutput tables would cause an overestimation of direct household energy consumption and concomitantly an underestimation of indirect household energy consumption.

This study shows that average direct and total energy intensities declined rather substantially in the 1995 to 2010 period in Korea. This means that the Korean industry moved to a higher value added production structure as the value added of the Korean production grew faster than the energy input (use) for the production. Energy intensive sectors belong mostly to heavy and chemical industries. In 2009, electricity consumption became the main source of household energy consumption in Korea. Households consume more and more electricity intensive goods and services, a sign of increasing living standards. This occurred despite relatively low energy intensity of electricity in Korea.

The Korean household sector was responsible for between 55\% in 2005 and $65 \%$ 
in 1995 of the energy related energy consumption in the 1995 to 2010 period. And more than $69 \%$ of household energy consumption was indirect. Thus, the household sector is the main economic sector (driver) in energy consumption and not only direct but also indirect household energy consumption should be the policy target of energy conservation. Decrease in energy intensities of products consumed by Korean households contributed greatly to reduce the increase in the total household energy consumption. However, switching took place towards more energy intensive products, thus the structure effect was negative. It is necessary to direct consumption and production towards much less energy intensive goods and services as to reduce energy consumption or its growth rate. The Korean government should readjust low energy and electricity prices to cost-reflective prices levels as these low prices are one of the main reasons for the consumption of more energy intensive products.

The share of direct household energy consumption in the total household energy consumption is low probably because higher fuel prices for gasoline and electricity discouraged direct household energy use, hence low energy consumption, while lower fuel prices for the industry lead to an energy intensive industrial structure and with it to higher share of indirect use. It exemplifies that higher energy prices are a strong measure for energy conservation and energy conservation. Another reason for the high share of indirect energy consumption could be found in a relatively high share of heavy industry in the economy as well as in the total final energy consumption (TFC).

Information on energy intensities of more disaggregated sectors/ products will encourage household energy conservation. Many consumers do not pay adequate attention to energy conservation as they do not have such information (Hassett and Metcalf, 1993; Ürge-Vorsatz et al., 2006).

Korea's energy consumption per GDP production was much higher than other OECD countries in comparison as shown in Table 6. Korea should make more effort to reduce energy consumption. In this regard, indirect and total household 
energy consumption should be the main target for energy conservation.

More research should be done on indirect household energy consumption. A future Korean study should apply a hybrid method to assess indirect household energy consumption more accurately. Intensities of energy intensive products and expenditure strong products need to be assessed by the process chain analysis as to reduce errors occurred by using uniform (average) prices within the individual sector in constructing energy input-output tables and as to make energy intensities of different years more comparable.

\section{[참고문헌]}

1. Ang, B. W., Decomposition Methodology in Industrial Energy Demand Analysis. Energy 20(11), 1995, pp. 1081 95.

2. Bank of Korea (BOK). Input-output Tables. Various issues in CD-Rom, Seoul.

3. Boustead, I. and G. F. Hancock, Handbook of Industrial Energy Analysis. Ellis Horwood, Chichester, UK, 1979.

4. Bullard, C. W. and R. A. Herendeen, The energy costs of goods and services: an input-output analysis for the USA, 1963 and 1967. Energy Policy 3, 1975, pp. 268 78.

5. Bush, M. J., The energy intensities of commodities produced in Canada.Energy6, 1981, pp. 503 17.

6. Denton, R. V., The energy costs of goods and services in the Federal Republic of Germany, Energy Policy 3(4), 1975, pp. 279 84.

7. Farla, J., K. Blok, and E. Worrell, Monitoring of Sectoral Energy Efficiency Improvements in the Netherlands, 1980-1994, Department of Science, Technology and Society, Utrecht University, the Netherlands, 1997a.

8. Farla, J., K. Blok, and E. Worrell, Energy Efficiency Developments in the Pulp and Paper Industry. Energy Policy 25(7-9), 1997b, pp. 745 58.

9. Hassett, K. and G. Metcalf, Energy conservation investments: do consumers discount 
the future correctly? Energy Policy 21(6), 1993, pp. 710 16.

10. IFIAS, IFIAS Workshop Report 'Energy analysis and Economics'. Resources and Energy 1, 1978, pp. 151 204.

11. International Energy Agency (IEA), Energy Balances of OECD Countries (2012 Edition), in CD-ROM. Paris, France, 2012.

12. Lenzen, M., Primary energy and greenhouse gases embodied in Australian final consumption: an input-output analysis. Energy Policy 26(6), 1998, pp. 495 506.

13. Miller, R. E. and P. D. Blair, Input-Output Analysis: Foundations and Extensions. Eaglewood Cliffs, Printice-Hall, NJ, USA, 1985.

14. Ospelt, C., I. Knoepfel, and D. Spreng, Direkter und indirekter Energieverbrauch der Haushalte. Bulletin SEV/VSE 7, June, 1996.

15. Pachauri, S. and D. Spreng, Direct and indirect energy consumptions of households in India. EnergyPolicy30, 2002, pp. 511 23.

16. Park, H.-C. and E. Heo, The direct and indirect household energy consumptions in the Republic of Korea from 1980 to 2000: An input-output analysis. Energy Policy 35, 2007, pp. 2839 51.

17. Peet, N. J., Input-output methods of energy analysis. International Journal of Global Energy Issues. Special Issue on Energy Analysis 5(1), 1993, pp. 10 18.

18. Peet, N. J., A. J. Carter, and J. T. Baines, Energy in the New Zealand household, 1974-1980. Energy 10(11), 1985, pp. 1197 1208.

19. Pick, H. J. and P. E. Becker, Direct and indirect use of energy and materials in engineering and construction. Applied Energy 1(1), 1975, pp. 31 51.

20. Schaefer, H., 1982. Kumulierter Energieverbrauch zum Herstellen von Produkten Methoden der Ermittlung - Probleme der Bewertung. Brennstoff-Wärme-Kraft 34 (1982) Nr. 7.

21. Society for Environmental Toxicology and Chemistry (SETAC), Guidelines for Life-Cycle Assessment: A Code of Practice. Brussels, 1993.

22. Suh, S., M. Lenzen, G. J. Treloar, K. Honko, A. Horvath, G. Huppes, O. Jolliet, U. Klann, W. Krewitt, Y. Moriguchi, J. Munksgaard, and G. Norris, System Boundary Selection in Life-Cycle Inventories Using Hybrid Approaches, Environmental Science \& Technology 38(3), 2004, pp. 657 64. 
23. Suh, S. (Ed.), Handbook of Input-Output Economics for Industrial Ecology, Springer, Dordrecht, the Netherlands, 2006.

24. Ürge-Vorsatz, D., S. Koeppel, A. Novikova, Improving Energy-efficiency in Buildings: opportunities, promises, challenges and solutions. In Proceedings of Seoul Conference on Using energy and materials more efficiently: A precondition for sustainable development. Korea Resource Economics Association, Korea Energy Economics Institute, Centre for Energy Policy and Economics of ETH Zurich and Ecofys, Seoul, Korea, September, 2006, pp. 29 56.

25. van Engelenburg, B. C. W., T. F. M. van Rossum, K. Vringer, K. Blok, Calculating the energy consumptions of household purchases: A practical step by step method. Energy Policy 22(8), 1994, pp. 648 56.

26. Vringer, K., K. Blok, The direct and indirect energy consumptions of households in the Netherlands. Energy Policy 23(10), 1995a, pp. 893 910.

27. Vringer, K., K. Blok, Consumption and energy-consumption: A time series for households in the Netherlands from 1948 to 1992, NW \& Sonderzoeksrapport No. 95016, University of Utrecht, the Netherlands, 1995b.

28. Vringer, K., K. Blok, Long-term trends in direct and indirect household energy intensities: a factor in dematerialization? Energy Policy 28, 2000, pp. 713 27.

29. Vringer, K., K. Blok, van B. Engelenburg, A Step-Wise Guide for Energy Analysis: How to Calculate the Primary Energy Requirements of Households? In: Suh, S. (Ed.). In: Handbook of Input-Output Economics for Industrial Ecology, Springer, Dordrecht, the Netherlands, 2009, pp. 491 505.

30. Wright, D. J., Goods and Services: An input-output analysis. Energy Policy 2, 1974, pp. $307 \sim 15$. 